\title{
PERFORMANCE AND HAEMATO - BIOCHEMICAL PROFILES OF WEST AFRICAN DW ARF (WAD) DOES FED SELECTED CROP BY-PRODUCTS IN NIGERIA
}

\author{
Kalio, G. $\mathrm{A}^{1^{*}}$ and Anyanwu, N. J.2 \\ ${ }^{1}$ Department of Agricultural Science, Ignatius Ajuru University of Education, Ndele Campus, P.M.B. \\ 5047, Port Harcourt, Nigeria. \\ 2Department of Animal Science and Technology, Federal University of Technology, P.M.B.1526, \\ Owerri, Nigeria. \\ *Correspondence: ag.kalio@yahooo.com +2348033000589
}

\begin{abstract}
This study was conducted to investigate the performance and haemato-biochemical parameters of WAD Does fed crop by-products: Yam peels( $\left.T_{1 Y P}\right)$ Cassava peels ( $\left.T_{2 C P}\right)$, Sweet potato peels ( $\left.T_{3 S P P}\right)$ and Ripe plantain peels ( $T_{4 R R P}$ ) in humid tropical Cross Rivers State of Nigeria. Sixteen (16) twenty (20) weeks old West African Dwarf (WAD) Does with average initial body weights of $7.308 \pm 1.41 \mathrm{~kg}$ were used. The four crop by-products used were replicated 4 times with 1 Doe per replicate in a completely randomized design (CRD). Feed dry matter intake (FDI), final body weight (FBW), final weight gains (FWG) and feed conversion ratios $(F C R)$ were significantly $(P<0.05)$ different. The haematological values and blood biochemistry for the WAD Does in all the treatment groups fell within the reference range for normal goats in terms of WBC $(4-13 \times 103 / \mu \mathrm{L}), \mathrm{RBC}(8.0-18.0 \times 106 / \mu \mathrm{l})$, MCV $(16-25 \mathrm{fl}), \mathrm{MCH}(5.2-8.0 \mathrm{pg})$, MCHC (30 - $36 \mathrm{~g} / \mathrm{dl}), \mathrm{Hb}(8-12 \times \mathrm{g} / \mathrm{dl})$, PCV $(24-48 \%)$, PLT (3- $6 \times 1011 / \mathrm{L})$ and GLUC $((2.7-4.2$ $\mathrm{mmol} / \mathrm{L})$, CREAT $(59.7-134.8 \mu \mathrm{mol} / \mathrm{L})$, CHOLES $(1.54 \mathrm{mmol} / \mathrm{L}), \mathrm{BUN}(32.25-37.30 \mathrm{mg} / \mathrm{dl}), \mathrm{K}(3.8-$ $5.7 \mathrm{mmol} / \mathrm{L}), \mathrm{Na}(136.6$ - $151.5 \mathrm{mmol} / \mathrm{L}), \mathrm{CL}(100.3-111.5 \mathrm{mmol} / \mathrm{L}), \mathrm{Ca}(2.25-2.90 \mathrm{mmol} / \mathrm{L}), \mathrm{P}(3.7$ $5.7 \mathrm{mg} / \mathrm{dl}$ ) respectively. The WAD Does fed $\mathrm{T}_{2 \mathrm{CP}}$ exhibited superior performance characteristics. Consequently, the utilization of crop by-products used in this study has no deleterious effects on the nutritional and health conditions of the WAD Does and is recommended for use in goat production systems.
\end{abstract}

Key words: By-products, Performance, WAD Does, Haematology and Serum biochemistry.

\section{INTRODUCTION}

The West African Dwarf (WAD) goats are trypano-tolerant breeds of goats found within the rain forest and derived savannah zones and has contributed to the animal protein intake of over 19 million people in Nigeria (Obua et al., 2012). This is as a result of the flourishing trade in the demand for these animals due to their socio-economic importance and the acceptability of the meat of the animal by all tribes and religion in Nigeria. The integration of livestock and crops in farming systems encourages utilization of crop by-products and allows effective recycling of waste products in livestock production system. There has been evidence that large quantities of crop by-products produced at homes, on private and government farms in Nigeria is wasted year after year. Some are thrown away in garbage bins, while others are left to rot in the field or burnt (Onyeonagu and Njoku, 2010). It has however, been reported that, West African Dwarf (WAD) goats when fed these crop by-products are able to meet up with their maintenance requirement and optimal productivity levels (Kalio, et al., 2013). The perceived acceptability rating of identified crop residues and agro industrial by-products revealed that cassava peels, yam peels, sweet potato and plantain peels are very much acceptable by sheep and goats in Nigeria (Onyeonagu and Njoku, 2010). 
Haematological and biochemical indices of animals give some insight as to the production performance potentials of West African Dwarf goats (Orheruata and Akhuomobhogbe, 2006). Similarly, Haematological constituents reflect the physiological responsiveness of the animal to its internal and external environments which include feed and feeding (Esonu et al., 2001). Furthermore, it has also been explained that a fast means of assessing clinical and nutritional health status of animal on feeding trails may be to use blood analysis, because blood contains a myriad of metabolites and other constituents, which provide a valuable medium for clinical investigation and nutritional status of man and animals (Okukpe et al., 2011). Consequently, nutrition, breed, sex, age, reproductive status, environmental factors, stress and transportation are known to affect haematological and biochemical parameters (Balikci et al., 2007). This study was carried out to provide information on the performance; haematology and biochemistry of West African Dwarf Does fed cassava peels, yam peels, sweet potato and plantain peels that are predominant and readily available in the Southern humid area of Nigeria.

\section{MATERIALS AND METHODS}

\section{Experimental site}

The experiment was conducted at the sheep and goat unit of the Teaching and Research farm of University of Calabar, Calabar, Nigeria. Calabar is located at about latitude $4^{\circ} 58 \mathrm{~N}$ and longitude $8^{\circ} 17$ $\mathrm{E}$ with an average annual temperature of $25-30^{\circ} \mathrm{C}$ and annual rainfall of $1,830 \mathrm{~mm}$ (Eze and Effiong, 2010).

\section{Management of Experimental Animals}

Sixteen (16) twenty (20) weeks old West African Dwarf (WAD) Does with average initial body weight of $7.308 \pm 1.41 \mathrm{~kg}$ known to be the predominant small ruminant species kept by small-holder crop-livestock owners adapted to the Southern humid (South-south geo-political) zone of Cross River State were used. The experimental goats were obtained from the households of small holder WAD goat owners residing in Okuku and Yache villages in Yala Local Government Area; Abouchiche and Ibiaragidi villages in Bekwara Local Government Area of Northern senatorial district of Cross River State. Their ages were determined by judging from their dentition (all milk teeth present indicating less than one year of age). They were dewormed using Albendazole oral suspensions for treatment against internal parasites. The treatment against possible attacks of ectoparasites was carried out using Ivomec, injected subcutaneously. The goats were randomly assigned to four (4) different crop by-products with four (4) replications of one Doe per replicate in a completely randomized design (CRD). They were allowed to come out on daily basis for exercise in an open palour $(25 \mathrm{~m} \times 25 \mathrm{~m})$ from $7.30-9.00$ am and provided with Penisetum purpureum as roughage to facilitate effective rumen function.

\section{Feed and feeding management}

Four (4) crop by-products: $T_{1 Y P}$ (yam peels), $T_{2 C P}$ (cassava peels), $T_{3 S P P}$ (sweet potato peels) and $T_{4 R P P}$ (ripe plantain peels) that abound and classified as common house hold food waste were used as dietary treatments fed to the experimental animals. The crop by-products were offered to the animals at $3 \%$ of their body weight (dry matter basis). Water and mineral licks (TANLICK@- 35.96\% Na, 0.25\% Zn, 0.30\% $\mathrm{Fe}, 0.20 \% \mathrm{Mn}, 0.003 \% \mathrm{I}, 0.002 \% \mathrm{Co}, 0.10 \% \mathrm{Cu}$, and $0.05 \% \mathrm{Mg}$ ) were provided ad libitum to the animals.

\section{Performance trial}

The performance trial involved the use sixteen (16) twenty (20) weeks old Does of the West African Dwarf (WAD) type. Four (4) Does were randomly assigned to each crop by-product: $T_{1 Y P}$ (yam peels), $T_{2 C P}$ (cassava peels), T3SPP (sweet potato peels) and T4RPP (ripe plantain peels). Four (4) replicates of one Doe per crop by-product were housed singly in an open pen $(3 \mathrm{~m} \times 4 \mathrm{~m})$ for the 90 days of the performance trial using the Complete Randomized Design (CRD). The animals were fed twice daily in the morning at $9.30 \mathrm{am}$ and in the evening at 4.00pm solely with each of the crop by-products at $3 \%$ of their body weights 
ad libitum when retired into their individual pens. They had regular access to fresh clean water and commercial mineral-salt licks (TANLICK®). Feed offered and left over were recorded on daily basis to determine the feed intake. Average weekly weight gains were computed by subtracting the initial weights of individual animals from the weekly final weights per treatment.

\section{Haematology and blood biochemistry}

On the last day of a 90-day experimental feeding and performance trial, two sets of blood samples were taken from 2 animals per dietary treatment from the Does via jugular veni puncture using a $10 \mathrm{ml} 20$ guage syringe. One set of the blood samples $(5 \mathrm{ml})$ was collected into plastic tubes containing the anti-coagulant ethylene diamine tetraacetic acid (EDTA) for the determination of haematological parameters. The other set of blood samples $(5 \mathrm{ml})$ was collected into anti-coagulant free plastic tubes, allowed to coagulate at room temperature and centrifuged for 10 minutes at $3000 \mathrm{rpm}$. The supernatant sera were then stored in a freezer for subsequent biochemical analysis.

Haematological values of the blood samples were estimated for packed cell volume (PCV) and haemoglobin $(\mathrm{Hb})$ concentration. Red blood cell (RBC) and total white blood cell (WBC) as well as the differential WBC counts were determined using the Neubauer haemocytometer after appropriate dilution. Constant values [mean corpuscular haemoglobin concentration (MCHC), mean corpuscular haemoglobin $(\mathrm{MCH})$ and mean corpuscular volume (MCV)] were calculated from the RBC, $\mathrm{Hb}$ and PCV values. Biochemical constituents of the serum samples estimated include calcium, sodium and potassium, inorganic phosphorus, chloride, urea, glucose, creatinine and cholesterol.

\section{Statistical analyses}

Analysis of variance (ANOVA) using general linear model (GLM) procedures (SAS, 1999) for Complete Randomized Design (CRD) was used to determine the treatment effects in the performance, haematological and biochemical data. Differences among the treatment means were separated using Duncan Multiple Range Test (Steel and Torrie, 1980).

\section{RESULTS AND DISCUSSION}

\section{Proximate composition of crop by-products}

The proximate composition (on \% DM basis) of the crop by-products: yam peels ( $\left.\mathrm{T}_{1 Y \mathrm{Y}}\right)$, cassava peels $\left(T_{2 C P}\right)$, sweet potato peels ( $\left.T_{3 S P P}\right)$ and ripe plantain peels ( $\left.T_{4 R P P}\right)$ used in this experiment is similar to previous data reported by Kalio et. al., (2013).

\section{Performance of WAD Does fed crop by-products}

The results of the performance of the WAD Does fed the different crop by-products in terms of weight gain are presented in Table 1. The initial weights of the animals allotted to the different feed treatment groups: $T_{1 Y P}$ (yam peels), $T_{2 C P}$ (cassava peels), $T_{3 S P P}$ (sweet potato peels) and $T_{4 R P P}$ (ripe plantain peels) were not significantly $(P>0.05)$ different. However, the average final total body weight and the average weight gains were significantly $(P<0.05)$ different.

The average final total weight ranged between $7900 \mathrm{~g}-10020 \mathrm{~g}$ for $T_{4 R P P}$ and $T_{2 C P}$, the average total weight gain and the average daily weight gain of the WAD Does for the treatment groups was also significantly $(P<0.05)$ different. The average total weight gain values varied from as high as $2720 \mathrm{~g}$ to as low as $600 \mathrm{~g}$ for $T_{2 C P}$ and $T_{4 R P P}$, respectively. The average total weight gain values of the animals varied from as high as $30.22 \mathrm{~g} /$ day to as low as $6.67 \mathrm{~g} /$ day for $T_{2 C P}$ and $T_{4 R P P}$, respectively. The values of daily weight gains recorded for the WAD goats is within the range of values $(6.55-31.90 \mathrm{~g} / \mathrm{day})$ reported by Fasae et al. (2007) in their study while improving the utilization of cassava peels. The observed variations 
in weight gain by the WAD Does fed the different crop by-products may be attributed to the various levels of metabolizable energy in the crop by-products as reported by Kalio, et al., (2013). Although the metabolizable energy of $T_{2 \mathrm{CP}}$ was lower than that of $T_{4 R P P}$ they were within the range $6-13 \mathrm{MJ} / \mathrm{kg} \mathrm{DM}$ necessary for optimal productivity (Steele, 2006). The superior weight gains exhibited by the WAD Does fed $T_{2 \mathrm{CP}}$ may also be attributed to the level of voluntary intake of the crop by-product (Bolu and Ibikunle, 2009). This is in agreement with McDonald, et al. (2010), who explained that the more food an animal consumes each day, the greater will be the opportunity for increasing its daily production. Thus, the WAD Does fed $T_{2 C P}$ possessed the highest weight gains (30.22g/day) and final weight (10020g). Conversely, the final weight of the WAD Does was lower than the values reported by Kalio, et. al. (2013) for WAD bucks fed cassava peels. This is in agreement with the reports by Bruce McGregor (2007) who reported that for a given age female goats will tend to be of lighter live weight than their male counterparts.

The results in Table 1 revealed that there were significant $(P<0.05)$ differences in the feed conversion ratio (FCR) among the WAD Does fed with the different crop by-products. However, the FCRs for T1YP (5.40) and $T_{2 C P}$ (6.30) were not statistically different for the animals. The WAD Does fed T4RRP utilized the crop by-product for body weight gain poorly when compared with other dietary groups. The poor intake may be due to heavy metals (lead and cadmium) and some anti-nutritional factors (Adeniji et al., 2008; Okukpe et al., 2012). This may have caused poor intake and a resultant reduction in weight. This is in support of the observation of Yousuf and Adeloye (2011) who explained that efficiency of feed utilization for production is a function of the nutrients profile of feeds as well as level of production.

\section{Haematology of WAD Does fed with the different crop by-products}

The results of the haematological parameters of the WAD Does fed with the various crop by-products: $T_{1 Y P}$ (yam peels), $T_{2 C P}$ (cassava peels), $T_{3 S P P}$ (sweet potato peels) and T4RPP (ripe plantain peels) is presented in Table 2. The white blood cells (WBCs) of the WAD Does were significantly $(P<0.05)$ different. The values ranged from $7.50-12.84 \times 103 / \mu \mathrm{L}$ for $\mathrm{T}_{2 \mathrm{CP}}$ and $\mathrm{T}_{4 R P P}$ respectively. The values of WBC are slightly higher than those reported by WAD bucks (Kalio et al., 2014) but within the normal range $(4-13 \times 103 / \mu \mathrm{L})$ for healthy goats (Aiello, 2000). This condition exhibited by the WAD Does revealed that there were no microbial infections or presence of foreign bodies or parasites in the circulatory system of the experimental animals (Bello and Tsado, 2014) which further indicates that the feeding of the crop by-products do not affect the immune system of the WAD Does (Etim, 2015). Similarly, the lymphocyte for the WAD Does were significantly $(P<0.05)$ different. The values ranged from 51.95 $-65.18 \%$ for $\mathrm{T}_{2 \mathrm{CP}}$ and $\mathrm{T}_{4 \mathrm{RPP}}$ respectively. These values are within the normal range $(50-70 \%)$ for goats, reported by Aiello (2000). This gives a clear indication that the use of these crop by-products is not deleterious to the WAD Does (Kalio et al., 2014).

The red blood cells (RBCs) of the WAD Does fed with the various crop by-products (Table 2) were significantly $(P<0.05)$ different. The RBCs values for the WAD Does ranged from $13.00-16.79 \times 106 / \mu \mathrm{L}$ for $T_{2 C P}$ and $T_{4 R P P}$ respectively. These RBC values recorded for the WAD Does were within the values $(8.0$ - $18.0 \times 106 / \mu l)$ reported by Banerjee (2004) and Aiello (2000) for normal goats. This condition reveals that the utilization of these feed stuffs ensures effective transport of haemoglobin through the RBCs of the animals. There is a clear indication of effective oxygen transportation within the tissues of the WAD Does for oxidation of digested food for release of energy for bodily functions (Etim, 2015).

The haemoglobin value of the WAD Does fed with the various crop by-products (peels) were significantly $(P<0.05)$ different (Table 2). The haemoglobin of the WAD Does ranged from $7.50-8.55 \mathrm{xg} / \mathrm{dl}$ for $\mathrm{T}_{4 R P P}$ and $T_{1 Y P}$ or $T_{2 C P}$ respectively. The haemoglobin values of the WAD Does fed $T_{1 Y P}, T_{2 C P}$ and $T_{3 S P P}$ were within the normal range (8-12 x g/dl) for goats (Aiello, 2000; Ikhimioya and Imasuen, 2007). However, WAD Does fed with T4RPP exhibited lower haemoglobin values. This may be due to the lower Iron ( $\mathrm{Fe})$ contents in the ripe peels (Igodharo, 2012). The haemoglobin values reported for the WAD Does with fed 
$\mathrm{T}_{1 Y \mathrm{Y}}, \mathrm{T}_{2 \mathrm{CP}}$ and $\mathrm{T}_{3 \mathrm{SPP}}$ were relatively high and seemed to be capable of supporting high oxygen carrying capacity of blood in the animals (Ikhimioya and Imasuen, 2007).

The PCV values of the WAD Does fed with the various crop by-products (peels) were significantly ( $P<$ 0.05 ) different (Table 2). The PCV values ranged from $29.90-39.60 \%$ for $T_{4 R P P}$ and $T_{2 C P}$ respectively. The PCV values reported for the WAD Does in this study were within the normal range $(24-48 \%)$ reported by Banerjee (2004) for healthy goats. However, the average values (35.68\%) for all the treatment groups were higher than the PCV values (30.0\%) for Does reported by Opara et al. (2010) for apparently healthy West African Dwarf (WAD) goats in Owerri South Eastern Nigeria. This variation may be due to differences in the plane of nutrition of the animals in this study and those reported by lkhimioya and Imasuen (2007). The higher PCV values reported in this study for the WAD Does corroborates with the increase in the RBCs of Does fed the different crop by-products. This is in agreement with the reports by Etim, et al. (2014), who explained that high packed cell volume (PCV) readings indicated either an increase in number of red blood cells or reduction in circulating plasma volume.

Table 2 shows results for the platelets or thrombocytes for WAD Does fed with the different crop byproducts. The platelets values for WAD Does in this study were not significantly $(P>0.05)$ different. However, the values recorded for WAD Does were within normal range 3-6 $\times 1011 / \mathrm{L}$ for goats reported by Aiello (2000). The blood indices or the Red blood cell indices: MCV, MCH and MCHC values for the WAD Does fed with the different crop by-products were significantly $(P<0.05)$ different. The MCV, MCH and $\mathrm{MCHC}$ values reported for the WAD Does in this study were within the normal range $16-25 \mathrm{fl}, 5.2$ $-8.0 \mathrm{pg}$ and $30-36 \mathrm{~g} / \mathrm{dl}$ respectively reported by Aiello (2000) and Banerjee (2004). The normal Red blood cell indices recorded in this study for WAD Does fed with the different crop by-products gives a clear indication that the animals were not anaemic.

\section{Blood biochemistry of West African Dwarf (WAD) Does fed with the different crop by products (peel)}

Table 3 shows results for the blood glucose values of WAD Does fed with the different crop by-products: $T_{1 Y P}$ (yam peels), $T_{2 C P}$ (cassava peels), $T_{3 S P P}$ (sweet potato peels) and $T_{4 R P P}$ (ripe plantain peels). The blood glucose value for the WAD Does fed with the different crop by-products were not significantly $(P>$ 0.05 ) different. However, WAD Does fed with $T_{2 c P}$ had superior numerical values of blood glucose when compared to those fed other crop by-products (T1YP, $T_{3 S P P}$ and $T_{4 R P P}$ ). This is similar to the observations by Kalio, et. al., (2014) in their studies with WAD bucks. This may be attributed to the conformity of this cassava peels to the recommended energy value for an average diet (6 - $13 \mathrm{MJ} / \mathrm{kg} / \mathrm{DM})$ (Steele, 2006). Furthermore, the blood glucose values for the WAD Does fed with the different crop by-products were within the normal range $(2.7-4.2 \mathrm{mmol} / \mathrm{L})$ for goats (Aiello, 2000). This numerical blood glucose value portrayed by $\mathrm{T}_{2 \mathrm{CP}}$, although not statistically significant, further reflected in the performance in terms of average final weights, average weight gain (g/day) and feed intake (Table 1). Conversely, WAD Does that exhibited low glucose values as was observed in WAD Does fed with $\mathrm{T}_{4 R R P}$ showed poor performance in terms of average final weights and average weight gains (g/day) and feed intake (Table 1). This corroborates the reports of Lazzaro (2001) who explained that gross reduction in weight gain, milk yield and alteration in the fatty composition in the milk of livestock are due to very low level of glucose in blood. Therefore, blood glucose values exhibited by the WAD Does in this study are indicative of their nutrient (energy) status (Turner et. al., 2005).

The creatinine levels for the WAD Does fed with the different crop by-products were not significantly ( $P$ $>0.05$ ) different (Table 3). The creatinine levels recorded for the WAD Does were 68.76, 70.37, 73.75 and $75.40 \mu \mathrm{mol} / \mathrm{L}$ for $\mathrm{T}_{1 Y \mathrm{YP}}, \mathrm{T}_{2 \mathrm{CP}}, \mathrm{T}_{3 \mathrm{SPP}}$ and $\mathrm{T}_{4 \mathrm{RPP}}$ respectively. The average creatinine levels recorded in this study for the WAD Does are slightly higher $(72.07 \mu \mathrm{mol} / \mathrm{L})$ than those recorded $(70.72 \mu \mathrm{mol} / \mathrm{L})$ for WAD bucks in South eastern Nigeria by Opara et al. (2010). However, these levels were within the 
baseline serum creatinine ranges $(59.7-134.8 \mu \mathrm{mol} / \mathrm{L})$ reported irrespective of the sex and breeds of goats by Aiello (2000) and also implies that the animals had properly functioning kidneys.

The serum cholesterol levels for the WAD Does were significantly $(P<0.05)$ different (Table 3$)$. The cholesterol levels for the WAD Does ranged between 1.16 and $1.59 \mathrm{mmol} / \mathrm{L}$ with the WAD Does fed T2CP exhibiting lower cholesterol levels as against the T4RPP group with the highest cholesterol levels respectively. The average serum cholesterol levels for all the treatment groups were $1.28 \mathrm{mmol} / \mathrm{L}$ for the WAD Does. This level of serum cholesterol recorded is slightly higher than those reported by Opara et al. (2010) among WAD Does (1.25 mmol/L), but within the reference range of serum cholesterol levels $(1.7-3.5)$ for a normal goat reported by Aiello (2000). The serum cholesterol levels for the WAD Does in this study was low. This reveals that the WAD Does were normal and not susceptible to heart disease (Chatterjea and Shinde, 2007).

The blood urea nitrogen (BUN) levels for the WAD Does fed with the different crop by-products were significantly $(P<0.05)$ different (Table 3$)$. The BUN levels for the WAD Does ranged between $32.45-$ $37.04 \mathrm{mg} / \mathrm{dl}$ for the T1YP and T4RPP group respectively. The BUN levels within the range $(32.25-37.30$ $\mathrm{mg} / \mathrm{dl}$ ) for WAD goats fed with feedstuffs with crude protein (CP) ranging between $8.44-29.85 \%$ (Ikhimioya and Imasuen, 2007), although the CP levels of the crop by-products used in this study were lower $(6.07-7.37 \%$ ) (Kalio et. al., 2013). However, the BUN levels in this study were within the recommended limits which suggest that the kidneys and liver in the body of the WAD Does were functioning well since BUN levels provide supplemental information as regards renal functions (Ostfeld et al., 2010).

The blood potassium $(K)$ levels for the WAD Does fed with the different crop by-products were significantly $(P<0.05)$ different (Table 3). The blood $\mathrm{K}$ levels for the WAD Does were within the range of $4.39-5.45$ mmol/L for the animals fed $T_{3 S P P}$ and $T_{2 C P}$ respectively. The $\mathrm{K}$ levels recorded in this study for the WAD Does were within the reference serum $\mathrm{K}$ values $(3.8-5.7 \mathrm{mmol} / \mathrm{L})$ for normal goats reported by Aiello, (2000). Therefore, the maintenance of this serum K levels by the WAD Does in this study suggests that this substance was able to maintain cellular tonicity, maintain fluid balance and $\mathrm{PH}$, regulate metabolic processes as well as involved in regulation of neural and muscular functions (Cheesebrough, 2004).

The blood sodium $(\mathrm{Na})$ for the WAD Does fed with the different crop by-products were significantly $(\mathrm{P}<$ 0.05 ) different. The blood Na levels for the WAD Does ranged between $138.55-146.40 \mathrm{mmol} / \mathrm{L}$ for the $T_{2 C P}$ and $T_{4 R P P}$ groups respectively. The Na levels recorded for the WAD Does in this study were within the reference serum Na values (136.6 - $151.5 \mathrm{mmol} / \mathrm{L})$ for normal goats reported by Aiello (2000). The maintenance of this serum Na levels by WAD Does in this study suggests that this substance was able to maintain cellular tonicity fluid balance and $\mathrm{PH}$, regulate metabolic processes as well as involved in regulation of neural and muscular function (Cheesebrough, 2004). Furthermore, Na and $\mathrm{K}$ as electrolytes are used to assess renal functions and since these values were within the normal range described, it implies that the normal body functions of the WAD Does were maintained when fed with the different crop by-products.

The serum chloride $(\mathrm{Cl})$ levels for the WAD Does fed with the different crop by-products were not significantly $(P>0.05)$ different (Table 3$)$. The serum $(C l)$ levels recorded for the WAD Does fed with the different crop by-products were $104.50,106.00,107.67$ and $108.00 \mathrm{mmol} / \mathrm{L}$ for $\mathrm{T}_{3 \mathrm{SPP}}, \mathrm{T}_{2 \mathrm{CP}}, \mathrm{T}_{1 Y \mathrm{YP}}$ and $\mathrm{T}_{4 R P P}$ respectively. The Na levels recorded in this study for the WAD Does were within the reference serum $\mathrm{Na}$ values (100.3 - $111.5 \mathrm{mmol} / \mathrm{L})$ for normal goats reported by Aiello, (2000). The maintenance of the serum chloride within the normal range for goats in this study suggests that the feeding of these crop by-products to the WAD Does do not have any deleterious effects as to cause nephritis, diabetic acidosis or excessive fluid loss (Cheesebrough, 2004). 
The blood calcium $(\mathrm{Ca})$ levels for the WAD Does fed with the different crop by-products were not significantly $(P>0.05$ ) different (Table 3). The blood Ca levels for the WAD Does fed the crop by-product ranged between $2.43-2.86 \mathrm{mmol} / \mathrm{L}$ for the $T_{1 Y P}$ and $T_{4 R P P}$ groups respectively. The Ca levels recorded in this study for the WAD Does were within the reference serum Ca values $(2.25-2.90 \mathrm{mmol} / \mathrm{L})$ for normal goats reported by Aiello (2000). The maintenance of the normal serum calcium levels by WAD Does in this study reveals that the feeding of these crop by-products does not have any deleterious effects as to cause hyperparathyroidism, hypervitaminosis $\mathrm{D}$, multiple myoloma and neoplastic disease or osteomalacia, rickets and renal failure in them (Cheesebrough, 2004).

The blood phosphorus (P) levels for the WAD Does fed with the different crop by-products were significantly $(P<0.05)$ different (Table 3). The blood $P$ levels for the WAD Does were within the range of $4.32-5.00 \mathrm{mg} / \mathrm{dl}$ for the animals fed with $\mathrm{T}_{3 \mathrm{SPP}}$ and $\mathrm{T}_{2 \mathrm{YP}}$ respectively. The $\mathrm{P}$ levels recorded in this study for the WAD Does were within the reference serum $P$ values $(3.7-5.7 \mathrm{mg} / \mathrm{dl})$ for normal goats reported by Aiello, (2000). Therefore, the maintenance of the serum phosphorus within the normal range by WAD Does in this study shows that feeding of these crop by-products to WAD Does do not have any deleterious effects since a significant increase of the serum inorganic $P$ level is often associated with nephritis and slight increase and may be associated with decreased parathyroid activity, while a decrease could indicate rickets and other related problems (Cheesebrough, 2004).

\section{CONCLUSION AND RECOMMENDATIONS}

The crop by-products investigated in this study: Yam peels ( $\left.T_{1 Y P}\right)$, Cassava peels $\left(T_{2 C P}\right)$, Sweet potato peels ( $\left.T_{3 S P P}\right)$ and ripe plantain peels ( $\left.T_{4 R R P}\right)$ is of little or no competitive demand for use by man. Hence they can be useful as feed resources for small-holder goat producers. However, $T_{2 \mathrm{CP}}$ (cassava peels) has proven beyond reasonable doubt based on performance parameters as a better crop by-product for use by WAD Does. Consequently, the utilization of these crop by-products has no deleterious effects on general performance and health conditions of the Does and is recommended for use in goat production systems.

\section{REFERENCES}

Adeniji1, T. A., Samuel, I., Barimalaa, A., Tenkouano, L., Oladimeji, S. and Hart, A.D. (2008). Antinutrients and heavy metals in new Nigerian Musa hybrids peels with emphasis on utilization in livestock production. Fruits.63 (2): 3-9.

Aiello, S.E. (2000). The Merck Veterinary Manual.8th Edition. Merck \& Co., Inc, White House, N.J., U.S.A.

Balikci, E., Yildiz, A. and Gurdogan, F. (2007). Blood metabolite concentrations during pregnancy and post-partum in Akkaraman ewes. Small Ruminant Research. 67: 247-251.

Banerjee G.C. (2004). A text book of Animal Husbandry. 8th ed. Oxford \& IBH Publishing Co. PVT, LTD, New Delhi.

Bello A.A. and Tsado, D.N. (2014). Quality and sensory evaluation of meat from Yankasa rams fed sorghum stover supplemented with varying levels of dried poultry droppings based diet. International Journal. of Agriculture and Food Science and Technology. 5 (2): 1 - 8.

Bolu, S.A. and Ibikunle, M. (2009). Comparative cost/benefit of Alternative/Conventional Feedstuff In Broiler Production In Nigeria. Agrosearch. 10(1\&2): 55 -63.

Bruce McGregor, A. (2007). Meat and offal yields of goats. Retrieved on 25th November, 2015 from http://www.dpi.vic.gov.au/dpi/nreninf.nsf/childdocs/ 89E7AFEA417624A2568B30004C26A137DAF9DA8A8FB47CA256BC700811CDA40ECIB639 E5CE0F64256DEA002783AE-9B8DD605BB8412DDCA256C1A0014A47B?open

Chatterjea, M. N. and Shinde, R. (2007).Textbook of Medical Biochemistry. 7th Edition, Jaypee Brothers Publishers (P) Ltd, New Delhi. 809pp. 
Cheesebrough, M. (2004).District Laboratory Practice in Tropical Countries Part 1. Low Priced Edition, Cambridge: Cambridge University Press. 454pp.

Esonu, B.O., Emenalom, O.O., Udedibie, A.B.I., Herbert, U, Ekpor, C.F., Okoli I.C. and Iheukwumere, F.C. (2001). Performance and blood chemistry of weaner pigs fed raw mucuna beans (velvet bean) meal. Tropical Animal Production and Investigation, 4: 49-54.

Etim, N.N., Enyenihi, G.E., Akpabio, U. and Offiong, E.A. (2014). Effects of nutrition on haematology of rabbits: A review. European Scientific Journal. 10 (30): 413-424.

Etim, N.N. (2015). Reference values for haematological parameters of sheep: A Review. The American Journal of Innovative Research and Applied Sciences. 1(1):14-21.

Eze, E.B and Efiong, J. (2010). Morphometric Parameters of the Calabar River Basin: Implication for Hydrologic Processes. Journal of Geography and Geology. 2 (1): 22-24.

Fasae, O.A., Adegoke, H.B., Ogunmekan, K.O. and Adu, I.F. (2007). Improving the feed utilization of cassava peels in smallholder goat production. Nigerian Journal of Animal Production. 34(2): 251-257.

Ikhimioya, I. and Imasuen J.A. (2007) Blood profile of West African Dwarf Goats fed Panicum maximum supplemented with Afzelia africana and Newbouldia laevis. Pakistan Journal of Nutrition. 6 (1): $79-84$.

Ighodaro, O.M. (2012). Evaluation study on Nigerian species of Musa paradisiaca Peels:Phytochemical screening, proximate analysis, mineral composition and ntimicrobial activities. Researcher, 4(8): $17-20$.

Kalio, G. A., Ayuk, A. A. and Agwunobi, L. N. (2013). Performance and economics of production of West African Dwarf (WAD) bucks fed crop by-products as sole feed in Cross River State, Nigeria. World Journal of Agricultural Science, 1(3): 81 - 87.

Kalio, G.A., Okafor, B.B. and Ingweye, J.N. (2014). Haematology and Biochemistry of West African Dwarf (WAD) Bucks fed crop by-products in Humid Tropical Nigeria. The Experiment. 18 (2): 1227 1234.

McDonald, P., Edwards, R.A., Greenhalgh, J.F.D., Morgan, C.A., Sinclair, L.A and Wilkinson, R.G. (2010). Animal Nutrition. 7th Edition, Pearson Publishers, Harlow, England.

Obua, B.E., Amaechi, N and Osodeke, S. (2012). Comparative Evaluation of Haematological Profile of West African Dwarf and Red Sokoto Goats reared in Humid South eastern Nigeria. International Journal of Agricultural and Rural Development, 15 (13): 1190 - 1197.

Okukpe K.M., Adeloye A.A., Badmos A.H.A., Adeyemi K.D and Olaniran T.O. (2011). Performance of West African Dwarf (WAD) Goats Fed Tridax and Siam Weed in Ficus Based Diets. Agrosearch, $11(1 \& 2): 11-18$.

Okukpe K.M., Belewu M.A., Adeyemi K. D. and Alli O. I. (2012). Performance Characteristics of West African Dwarf Goats Fed Trichoderma treated Jatropha Curcas Seed Cake. Agrosearch,1 (1): $69-76$.

Onyeonagu, C.C. and Njoku, O.L. (2010). Crop Residues and Agro-Industrial by-products used in traditional sheep and goat production in Rural Communities of Markudi Local Government Area. Journal of Tropical Agriculture, Food, Environment and Extension. 9 (3): 161 -169.

Opara, M.N., Udevi, N. and Okoli, I.C. (2010).Haematological Parameters and Blood Chemistry Of Apparently Healthy West African Dwarf (WAD) Goats in Owerri, South Eastern Nigeria. New York Science Journal. 3(8):68-72.

Orheruata, A. M. and Akhuomobhogbe, P. U., 2006. Haematological and blood biochemical indices in West African dwarf goats vaccinated against Pestes des petit ruminants (PPR). African Journal of Biotechnology, 5(9): 743-748.

Ostfeld, R., Spinelli, M., Mookherjee, D., Holtzman, D Shoyeb, A., Schaefer, M., Kawano, T., Doddamani, S., Spevack, D. and Duc, Y. (2010). The Association of Blood Urea Nitrogen Levels and Coronary Artery Disease. The Einstein Journal of Biology and Medicine, $3-7$. 
Steel, R.G.D and Torrie, J.H. (1980). Principles and procedures of Statistics. Biometric Approach. 2nd edition, McGraw Hill Co. Inc., New York, USA. 8-9 pp.

Steele, M. (2006). Goats. CTA-Macmillan Publishing Ltd., London and Basingstoke. Pp. 152.

Turner, K.E., Wildeus, S. and Collins, J.R. (2005). Intake, performance, and blood parameters in young goats offered high forage diets of lespedeza or alfalfa hay. Small Ruminant Research, 59: 15 23.

Yousuf, M.B. and Adeloye, A. A. (2011). Performance response of goats fed shed leaves (Vitellaria paradoxa, Gmelina arborea and Daniella oliveri) based diets. Nigerian Journal of Animal Production. 38 (1): $99-104$.

Table 1: Performance of West African Dwarf (WAD) Doe fed the crop by-products.

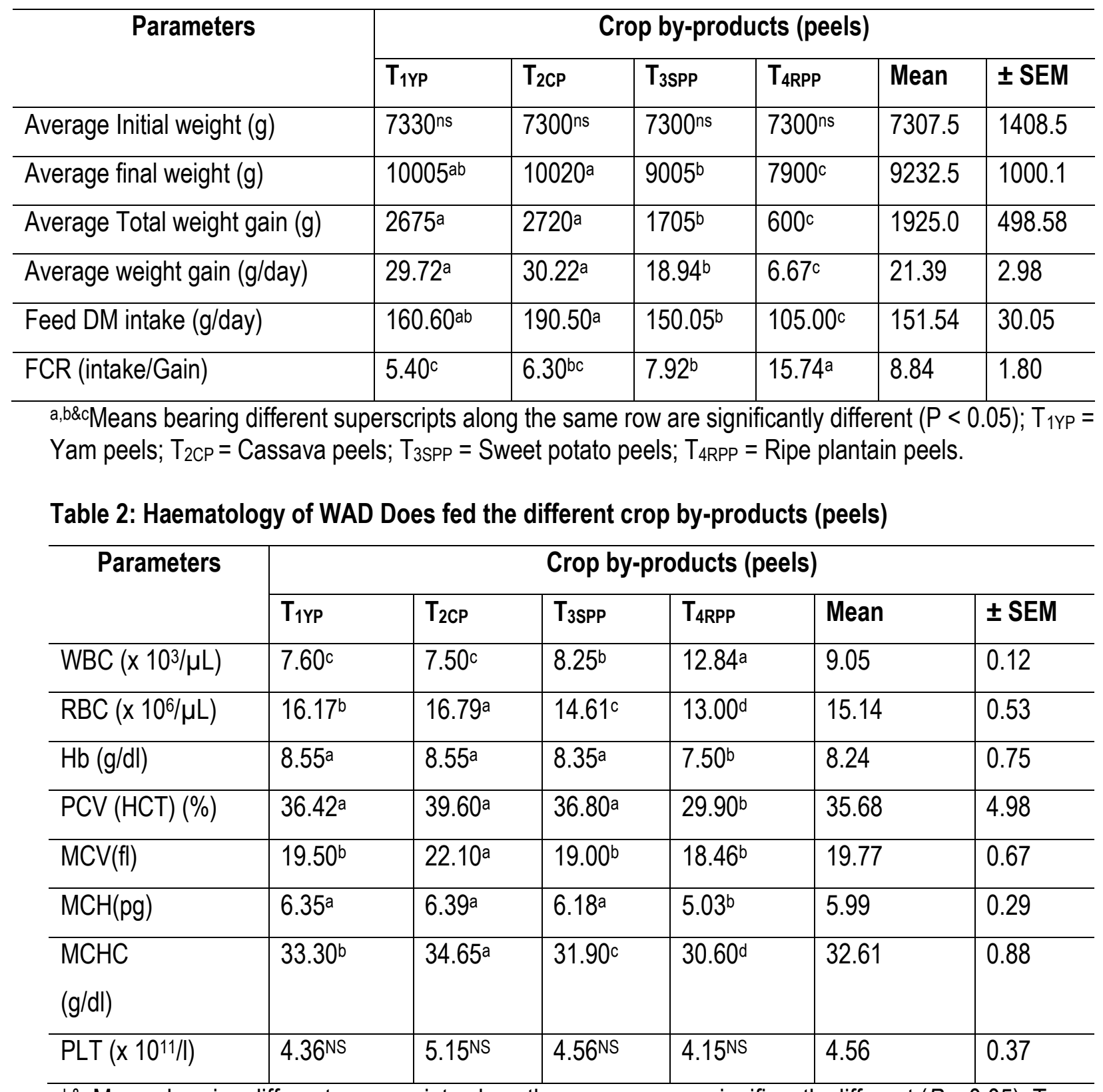

a,b\&c Means bearing different superscripts along the same row are significantly different $(P<0.05) ; T_{1 Y P}=$ Yam peels; $T_{2 C P}=$ Cassava peels; $T_{3 S P P}=$ Sweet potato peels; $T_{4 R P P}=$ Ripe plantain peels. $W B C=$ Whit e blood cells; RBC = Red blood cells; $\mathrm{Hb}=$ Haemoglobin; PCV $(\mathrm{HCT})=$ Packed cell volume (Haematocr it); $\mathrm{MCV}=$ Mean corpuscular volume; $\mathrm{MCH}=$ Mean corpuscular haemoglobin; $\mathrm{MCHC}=$ Mean corpuscul ar haemoglobin concentration; PLT = Platelets. 
Table 3: Blood biochemistry of WAD Does fed the different crop by-products (peels)

\begin{tabular}{|c|c|c|c|c|c|c|}
\hline \multirow[t]{2}{*}{ Parameters } & \multicolumn{6}{|c|}{ Crop by-products } \\
\hline & $T_{1 Y P}$ & $T_{2 C P}$ & $\mathrm{~T}_{3 \mathrm{SPP}}$ & $\mathrm{T}_{4 \mathrm{RPP}}$ & Mean & \pm SEM \\
\hline GLUC (mmol/L) & $2.52^{\mathrm{NS}}$ & $2.53^{\mathrm{NS}}$ & $2.32^{\mathrm{NS}}$ & $2.21 \mathrm{NS}$ & 2.40 & 0.14 \\
\hline CREAT ( $\mu \mathrm{mol} / \mathrm{L})$ & $68.76^{\mathrm{NS}}$ & $70.37 \mathrm{NS}$ & $73.75^{\mathrm{NS}}$ & $75.40^{\mathrm{NS}}$ & 72.07 & 2.21 \\
\hline CHOLES (mmol/L) & $1.18^{b}$ & $1.16^{b}$ & $1.18^{b}$ & $1.59^{a}$ & 1.28 & 0.12 \\
\hline BUN (mg/dl) & $32.45^{c}$ & $34.47^{b}$ & $36.79 a$ & $37.04^{a}$ & 35.19 & 1.24 \\
\hline $\mathrm{K}(\mathrm{mmol} / \mathrm{L})$ & $5.19 \mathrm{~b}$ & $5.45^{\mathrm{a}}$ & $4.39 \mathrm{~d}$ & $5.03^{c}$ & 5.02 & 0.2 \\
\hline $\mathrm{Na}(\mathrm{mmol} / \mathrm{L})$ & $141.56^{b c}$ & $138.55^{c}$ & $143.45^{b}$ & $146.40^{a}$ & 142.49 & 2.09 \\
\hline $\mathrm{Cl}(\mathrm{mmol} / \mathrm{L})$ & $107.67 \mathrm{NS}$ & $106.00^{\mathrm{NS}}$ & $104.50^{\mathrm{NS}}$ & $108.00^{N S}$ & 106.54 & 1.61 \\
\hline $\mathrm{Ca}(\mathrm{mmol} / \mathrm{L})$ & $2.43^{\mathrm{NS}}$ & $2.77 \mathrm{NS}$ & $2.53^{\mathrm{NS}}$ & $2.86 \mathrm{NS}$ & 2.65 & 0.27 \\
\hline INORGP (mg/dl) & $5.00^{a}$ & $4.82^{b}$ & $4.32^{d}$ & $4.56^{c}$ & 4.68 & 0.14 \\
\hline
\end{tabular}

